Микола Калько

\title{
АСПЕКТУАЛЬНА ПАРАДИГМА БАГАТОЗНАЧНОГО ДІССЛОВА (НА МАТЕРІАЛІ ПОЛІСЕМАНТА ЛАМАТИ)
}

У статті на матеріалі одного з багатозначних дієслів сучасної української літературної мови унаочнено можливість, доцільність та ефективність застосування об' єктивістського підходу до опису категорій аспектуальності та виду, що акиентує увагу на залежності оцінки внутрішньочасового характеру ситуачії від онтологічної специффіки екстралінгвальних корелятів дієслова, визначальної для способу їхньої мовної категоризаиії і неодмінно передбачає передовсім розмежування граматичного (категорії виду) та лексичного (аспектуальні класи) компонентів аспектуальності. Доведено, що такий підхід дає змогу, використовуючи відповідний дослідницький інструментарій, створити об'єктивну, удокладнену, а не спрощену, схематичну модель аспектуальної парадигми полісемічної дієслівної лексеми. У розвідиі представлено широку інтерпретацію иього поняття - як макропарадигми, щчо інтегрує: 1) аспектуально-лексичну мікропарадигму, наповнювану аспектуально-лексичними класами: термінативним, активітивним, стативним, евентивним, релятивним; 2) аспектуально-граматичну мікропарадигму, що об'єднує аспектуальнограматичні класи: імперфективи-партнери, перфективи-партнери, imperfektiva tantum, perfektiva tantum, 3) аспектуально-прагматичну мікропарадигму як набір конкретно-видових значень (функиій), передовсім - актуально-тривалого (конкретно-прочесного, прогресивного), ітеративного, preasens historicum, конкретно-фактичного тощо; 4) аспектуально-дериватологічну мікропарадигму, яка консолідує акиіональні підкласи (способи, або роди, дієслівної дії) як морфолого-словотвірні префіксальні, суфіксальні, конфіксальні деривати: атенуативи, делімітативи, дистрибутиви, дуративи, пердуративи, сатуративи, семельфактиви, кумулятиви, редуплікативи тощо. Визначальною для специфіки видової корелятивності, спектра функиій, набору акиіональних підкласів є належність до того чи того лексичного аспектуального класу.

Ключові слова: аспектуальна макропарадигма, аспектуально-лексична мікропарадигма, аспектуально-граматична мікропарадигма, аспектуальнофункиійна мікропарадигма, аспектуально-словотвірна мікропарадигма, аспектуальний клас, акціональний підклас, аспектуальне партнерство.

Вступ. Загальновідомо, що категорія виду серед основних граматичних категорій дієслова $€$ чи не найскладнішою та найдискусійнішою. Її називають «легендарною», «фатальною», «ареною боротьби лексики й граматики»,

(C) Калько М., 2020

DOI: 10.24025/2707-0573.2(3).2020.219289

ISSN 2707-0573 
порівнюють зі «складним клубком питань», «густим лісом проблем» (Карпухин, 2008, с. 3). Як було неодноразово підкреслено в багатьох аспектологічних працях, складність дослідження категорії виду (і ширше категорії аспекту, чи аспектуальності) полягає в багаторівневому характері iї змісту. Тому не дивно, що в останні десятиліття центральне місце у вивченні цієї категорії посідають питання, пов'язані саме з семантичним змістом самої категорії, а також зі значеннями, що виникають унаслідок взаємодії видових форм і того чи того типу контексту. Однією 3 основних причин постійного дослідницького невдоволення через відсутність адекватного наукового опису категорії виду $\epsilon$, на нашу думку, суб'єктивне намагання втиснути його в жорсткі й стерильні морфологічні рамки, абстрагуючись від усього його об'єктивного багаторівневого семантичного обширу.

Теоретичне підгрунтя. Чільним із дослідницьких орієнтирів у галузі дослідження аспектуальності як універсальної категорії та слов'янського виду як ідіоетнічної категорії є проблематика конференцій, які проводить Комісія 3 аспектології Міжнародного комітету славістів. Зокрема, четверта конференція «Семантичний спектр слов'янського виду», що проходила в Гетеборзькому університеті (Швеція) з 10 до 14 червня 2013 року, мала на меті продовження обговорення аспектуальної семантики в ракурсі всього «семантичного спектру виду» (терміносполука Ю. Маслова).

Як найбільш актуальну проблему для наукової полеміки авторка передмови до конференційних тез проф. Н. Зорихіна-Нільсон задекларувала співвідношення системи й середовища у сфері видових значень, що передбачає дослідження взаємодії категорійного значення виду й контексту для виявлення: 1) аспектуальної специфіки семантичних класів дієслів; 2) особливостей взаємодії виду й лексичного значення окремих дієслів; 3) взаємозалежності родів дієслівної дії з лексико-граматичними розрядами граничних vs неграничних дієслів (Nilsson, 2013, с. 13).

Рівень сучасних загальнотеоретичних і аспектологічних досліджень уможливлює здійснення комлексно-інтеграційного аналізу аспектуальності й виду. Урахування україністичної традиції вивчення виду першої половини XX ст., аспектологічних здобутків української формально-граматичної думки середини XX ст., загальнотеоретичного й аспектологічного доробку української функційно-категорійної граматики, загальнонаукової теорії взаємодії системи й середовища та іiі лінгвістичної інтерпретації, теорії функційно-семантичних полів (О. Бондарка та його послідовників) загалом та поля аспектуальності зосібна, концепції аспектуальних класів Ю. Маслова, лінгвофілософської теорії дієслівних класів 3. Вендлера, двокомпонентної теорії виду вможливлює створення аспектологічної концепції, основними складниками якої є, з одного боку, багатокомпонентна модель аспекту (виду), наріжні камені якої аспектуальні класи як регулятори видової поведінки дієслова, а 3 іншого інструмент дослідження цих класів і того впливу, який вони мають на вид, комплексна аспектологічна діагностика (Калько, 2013, с.113-168).

Роботи Ю. Маслова (Маслов, 1948) та З. Вендлера (Vendler, 1967) заклали підмурівок об’єктивістського підходу (термін Дж. Лайонза (Лайонз, 2003, с. 338)) до досліджень аспекту, зокрема, втіленого у двокомпонентну теорію виду - аспектологічну концепцію, зачинателем якої вважають американську лінгвістку К. Сміт, працям якої притаманний системний підхід до дослідження виду зосібна й аспектуальності загалом, що 
передбачає дихотомію: з одного боку, віртуальну універсально-граматичну схему аспектуальності, ізоморфну для всіх мов світу, а з іншого - ідіоетнічні конкретно-мовні варіанти іiі реалізації. Двома універсальними компонентами всіх аспектуальних систем, на думку дослідниці, $\epsilon$ ракурс і ситуаційний тип, між якими наявні певні співвідношення на різних мовних рівнях, передовсім морфемно-морфологічному, лексико-семантичному, синтаксичному, дериватологічному. Ракурсами $є$ перфектив, або доконаний вид, та імперфектив, або недоконаний вид. Вони відображають, мов об'єктив фотоапарата, ситуацію загалом або лише один із ії можливих фрагментів. Дія, процес, стан, подія становлять ситуаційні типи, що специфікують внутрішньочасовий характер відображуваних дієсловом ситуацій. Ракурси - це не що інше, як аспектуальні грамеми, а ситуаційні типи - аспектуально вагомі лексичні класи дієслів (Смит, 1998, с. 404-406). Застосування цієї теорії, представленої зокрема в роботах В. Броя, М. Гіро-Вебер, А. Залізняк, Б. Комрі, Ф. Леманна, Х. Р. Меліга, О. Падучевої, А. Пазельської, Г. Руддена, С. Татевосова та ін., уможливлює підхід до вивчення аспектуальної системи українського дієслова як двоєдиного феномена: з одного боку, граматичної, а з іншого - лексичної аспектуальності. Двокомпонентна теорія виду, по суті, і $є$ реалізацією об'єктивістського підходу до опису аспектуальності й виду, який на противагу суб'єктивістському акцентує увагу не так на погляді мовця на внутрішньочасову структуру процесуальної ознаки, на його аспектуальній оцінці ситуації, як на залежності цього погляду, цієї оцінки від онтологічної специфіки процесу, на глибокій закоріненості категорії виду у відображеній у лексичному значенні дісслів онтології позамовних явищ (дій, процесів, станів, відношень, властивостей, подій тощо).

Провідним дослідницьким імперативом об'єктивістського підходу є потреба аспектологічного аналізу всього спектра словозначень відповідного дієслова, оскільки аспектуальність та вид зорієнтовані не на всю дієслівну лексему, а на кожну їі семантему (лексико-семантичний та контекстуальний варіанти). Неврахування цього чинника, на нашу думку, є чи не основною причиною гострої полеміки навколо багатьох аспектологічних проблем, породжених намаганням утиснути вид у певні жорсткі категорійні рамки без урахування впливу на видову поведінку дієслова різнорівневих факторів. Як зауважує В. Плунгян, «конфлікт між «індивідуалізмом» лексики i «всеосяжністю» граматики - неодмінний наслідок обов'язкового характеру граматичних протиставлень, але, ймовірно, саме аспект (через його найбільшу семантичність) доводить цей конфлікт до найбільшої гостроти» (Плунгян, 1998, c. 30$)$.

Безперечно, проблема тісного зв'язку системи (категорії виду) із середовищем (передовсім - лексичною семантикою та синтаксичним контекстом) не могла залишитися поза увагою в лінгвоукраїністиці, іï відображено зокрема в працях В. Русанівського, А. Грищенка, І. Вихованця, К. Городенської, А. Загнітка, О. Бондаря, С. Соколової, В. Барчука та ін. Однак як об'єктивістський підхід загалом, так і проблему взаємодії категорії виду із внутрішнім та зовнішнім контекстами, окреслено лише в загальних рисах, що переконує в перспективній потребі глибшого лінгвістичного вивчення механізму взаємодії системи й середовища в царині категорії виду українського дієслова. 
У ракурсі виявлення аспектуальних парадигм як спектра значень, що належать до різних аспектуально релевантних лексичних класів дієслів, кожна полісемічна дієслівна лексема потребує скрупульозного аспектологічного «обстеження», застосування комплексної аспектологічної діагностики, яка вможливлює відтворення індивідуального аспектуального «портрета» багатозначного дієслова, до того ж, не абстрактно-віртуального, а актуально-реального, динамічного, що унаявнює вплив лінгвального й екстралінгвального довкілля на його видову поведінку, зокрема кореляційний (відсутність чи наявність видових партнерів-корелятів, а за наявності - тип видового партнерства: передовсім суто видового чи функційно-видового), акціональний (відсутність чи наявність, а відповідно - і спектр, акціональних дериватів - традиційних родів дієслівної дії) та функційний (спектр конкретно-видових функцій) потенціал.

Визначальними для видової поведінки дієслова складниками аспектуальної парадигми $\epsilon$ аспектуальні класи («характеры глагольного действия» (О. Ісаченко, О. Горбова), «аспекти дії» (А. Загнітко), «аспектуальні поля» (О. Бондар), «аспектуальные разряды» (М. Шелякін), «Aktionsgestalt» (Ф. Леманн), «акциональные классы», (О. Горбова) «способы глагольного действия» (Ю. Маслов, О. Бондарко, М. Шелякін), «способи дієслівної дії» (А. Грищенко), «роди дієслівної дії» (В. Русанівський, К. Городенська, С. Соколова), «совершаемости» (О. Ісаченко)), що постають у контексті нашого дослідження як аспектуально вагомі прихованограматичні, або лексико-граматичні, класи, які мають вплив на граматичну царину виду, імпліцитно регулюючи аспектуальну поведінку (передовсім корелятивну здатність, акціональний та функційний потенціал) дієслів. На грунті українського дієслова вони утворюють п'ятикомпонентну систему:

1) термінативи, або здійсненники, що об’єднують, $з$ одного боку, дієслова-імперфективи зі значенням подієспрямованого процесу, а з іншого дієслова-перфективи зі значенням здійснення цього процесу; 2) активітиви, або діяльники, що означають динамічний неподієспрямований процес; 3) стативи, або станівники, що описують адинамічний, недискретно-фазовий вияв буття, локалізований хоча б у межах надтривалого часового відрізка; 4) евентиви, або подійники, які передають значення миттєвих подій (як перфективи, так i імперфективи), зокрема i несподіваних, непередбачуваних, небажаних для суб'єкта; 5) релятиви, або відносники, що інтегрують дієслівні лексеми зі значенням процесуально-стилізованих відношень, властивостей, постійних ознак тощо (Калько, 2009; Калько, 2013, с. 72- 86).

Аспектологічний аналіз дієслівної лексики сучасної української мови засвідчує, що термінативність, активітивність, евентивність, стативність і релятивність - аспектуальна характеристика не дієслова загалом, а кожної його семантеми зосібна, яка залежить від конкретної реалізації валентного потенціалу предиката, чітко визначеного семантичного наповнення аргументів, передовсім суб'єкта, об'єкта, темпоратива, локатива, зрештою, широкого контексту.

Мета статті з огляду на сказане вище - застосування об'єктивістського підходу до опису категорії аспектуальності назагал та категорії дієслівного виду зосібна, що акцентує увагу на залежності оцінки внутрішньочасового характеру ситуації від онтологічної специфіки екстралінгвальних корелятів дієслова, визначальної для способу їхньої мовної категоризації, і неодмінно передбачає 
розмежування аспектуально-лексичного, аспектуально-граматичного, аспектуально-дериватологічного та аспектуально-прагматичного компонентів аспектуальності.

Методи та матеріал дослідження. Відтворити об'єктивну, удокладнену (а не схематичну, поверхову, спрощену) аспектуальну парадигму багатозначної дієслівної лексеми (у цій розвідці - полісеманта ламати в сукупності усіх його словозначень, зокрема й лексикографічно не зафіксованих, та контекстуальних слововживань) дає змогу комплексна аспектологічна діагностика як інтеграційна методика, що передбачає цілеспрямоване застосування логічного, компонентного, словотвірного, опозиційного та дистрибутивного аналізу, добір нативно-корелятивних контекстів, моделювання внутрішньочасової структури ситуацій за допомогою тестових діалогів тощо (Калько, 2013, с. 113-160).

Основні результати дослідження. Із погляду виявлення аспектуальної макропарадигми особливої уваги заслуговують безпрефіксні імперфективи з дифузною семантикою (бити, в'язати, драти, колоти, крутити, ламати, палити, рвати, різати, рубати тощо). Це засвідчує, зокрема, дослідження мотиваційної співвідносності та префіксальної дивергенції дієслова різати у роботі С. Соколової (Соколова, 2003, с. 45-49, с. 55-61). Комплексна аспектологічна діагностика таких дієслів дає змогу виявити всі тонкощі аспектуальної «палітри» дієслівного полісеманта. Об'єктом нашого дослідження послугувала одна 3 таких лексем - ламати як «поліпрефіксальний» (Ясаи, 1997, с. 75) корелятивний комплекс, до складу якого, $з$ одного боку, належать безпрефіксні імперфективи 3 дифузною семантикою, що уможливлює їхню корелятивну видову співвіднесеність iз кількома префіксальними перфективами, які, зі свого боку, корелюють зі вторинними імперфективами.

Комплексний об'єктивістський підхід до дослідження виду й аспектуальності передбачає моделювання аспектуальної парадигми полісемічного дієслова. Уперше термін «аспектуальна парадигма» запропоновала С. Соколова, визначивши эiі як частину парадигми похідних дієслів, зокрема тих, що відрізняються від основного дієслова за аспектом і / чи способом дії (Aktionsart). Основну увагу дослідниці закцентовано на семантичній специфіці базового дієслова, яка уможливлює поєднання з афіксами - носіями аспектної семантики і формування певного типу аспектної парадигми, зміни в якій викликає лексико-семантична варіація (Соколова, 2009; Соколова, 2016). У нашій розвідці представлено дещо ширшу інтерпретацію цього поняття - як макропарадигми, що інтегрує: 1) аспектуально-лексичну мікропарадигму, наповнювану аспектуально-лексичними класами: термінативним, активітивним, стативним, евентивним, релятивним; 2) аспектуально-граматичну мікропарадигму, що об’єднує аспектуальнограматичні класи: імперфективи-партнери, перфективи-партнери, imperfektiva tantum, perfektiva tantum, 3) аспектуально-прагматичну мікропарадигму як набір конкретно-видових значень (функцій), передовсім - актуально-тривалого (конкретно-процесного, прогресивного), ітеративного, preasens historicum, конкретно-фактичного тощо; 4) аспектуально-дериватологічну мікропарадигму, яка консолідує акціональні підкласи (способи, або роди, дієслівної діі) як морфолого-словотвірні префіксальні, суфіксальні, конфіксальні деривати: атенуативи, делімітативи, дистрибутиви, дуративи, пердуративи, сатуративи, семельфактиви, кумулятиви, редуплікативи тощо. Визначальною для специфіки видової корелятивності, спектра функцій, набору 
акціональних підкласів є належність до того чи того лексичного аспектуального класу.

Зокрема, комплексна аспектологічна діагностика дієслова ламати засвідчує, що найбільше його семантем відображають агентивні подієспрямовані процеси, тобто є термінативними. 3 огляду на те, що події, досягнуті внаслідок їхнього здійснення, позначають перфективи 3 дев'ятьма різними префіксами (ви-, від-, з-, над-, об-, пере-, по-, про-, роз-), доцільно виокремити щонайменше дев'ять термінативів, вісім із яких (крім ламати vs поламати) функціонують у складі видових трійок: перфективи перебувають у взаєминах суто видового партнерства 3 двома синонімічними імперфективами: 3 одного боку, безпрефіксним, від якого вони утворені, а $з$ іншого - з суфіксальним дериватом, утвореним від них унаслідок вторинної імперфективації:

1) ламати vs виламати vs виламувати: ламати (процес) «відривати, відокремлювати частину від цілого» vs виламати (подія): Але щзо ж тут з ним сперечатись, не тягнути ж його силою, - він швидше вниз стрибне, ніж дасть себе витягти. Треба було ламати кийка. Виламали аж три (В. Винниченко) vs виламувати (процес): Ляля підходить до тільки-но посаджених кущиів ясмину й виламує дубчика (Остап Вишня);

2) ламати vs відламати vs відламувати: ламати (процес) «відділяти, відокремлювати частину від цілого»: $A$ там я приведу в такі краї.., де ріки з киселю $i$ береги з житняку. Сідаєш на берег, ламаєш окрайця $i$ - ложкою в річку (Ю. Мушкетик) vs відламати (подія): Паляниця гріла мені груди, я підніс ï̈ до обличчя $і$ вдихнув - пахла вона чудово. Відламав шкурину, поклав до рота й жував (Вал. Шевчук) vs відламувати (процес): Якщо мав Росько при собі шматок коржа, то відламував крихту $і$ клав десь (В. Сліпачук);

3) ламати vs зламати vs зламувати: ламати (процес): «згинаючи що-небудь, надавлюючи на щось, відділяти, відламувати частини, шматки від чого-небудь»: Сашко хмуро стягає брови й, щуоб не заплакать, одвертається й починає ламати китиці бузку (В. Винниченко) vs зламати (подія): Підійшовши до берізки, Ігор Горенко схопився рукою за гілку, смикнув $i$ зламав ї̈ (В. Нестайко) vs зламувати (процес): Зламує дівчина з рожі квітку і пускає наводу: хай попливе та розкаже батькові-матері про ї̈ горе (В. Дяченко);

4) ламати vs надламати vs надломлювати: ламати (процес) «відокремлювати частину від чого-небудь»: Він тріщить, ламаючи сухі гілки, ілякає циим усіх, хто заходить до лісу (В. Нестайко) vs надламати (подія): I в порослих шаниях під жаб'яче голосіння копали просвирник. Мені він надламав якусь рогачку, а сам підкопував уламком кістки (М. Дочинець) vs надламувати (процес): Не перший раз Соломійка зрізувала чи надламувала вишневу гілку. Третій. Два попередні гілка у воді листочки розпускала, а от цввіту не було (В. Лис);

5) ламати vs обламати vs обламувати: ламати (процес): «відділяти краї, кінці чого-небудь»: - Людина тільки сама собі може обламати крила. А може, ми тільки розправляємо свої крила? - запитав Павлюк. - А лет у нас щее попереду? Гордій правду сказав: крила людина сама собі ламає, коли дух у неї перестає бути крилатим. Коли ї̈ відчай у панцир заковує (В. Чемерис) vs відламувати (подія): Де ви бачили орла, котрий сам собі обламував би крила? (В. Чемерис); 
6) ламати vs переламати vs переламувати: ламати (процес) «ділити, роз'єднувати на частини»: Лісовик (тупає зо злості ногою $і$ ламає з тріском свого цііпка) (Леся Українка) vs переламати (подія): Льонька перехопив вудку двома руками, а тодi - р-раз! - i переламав ї̈ об коліно (А. Кокотюха) vs переламувати (процес): Макс підіймає з землі сухий прутик, переламує на колінці й усе-таки мовчить та посміхається (В. Винниченко);

7) ламати vs проламати vs проламувати: ламати (процес) «псуючи ударами, поштовхами, робити вільним вхід, прохід, доступ куди-небудь у щось, руйнуючи перепону»: Одчиняй! Ламайте двері, поки вийде Старий паскуда! (Т. Шевченко) vs проламати (подія): Страшні твої нурти печерні, в пекельнім казані варись, та ненадовго, не барись, устигнеш проламати двері ... (В. Стус) vs проламувати (процес): Відчуття росло, і не в силі збагнути, що зі мною діється, я заплющив очі. Я став провалюватися кудись униз, проламував якісь стіни й підлогу (В. Лис);

8) ламати vs розламати vs розламувати: ламати «ділити, дробити на частини, шматки що-небудь»: Раніше, ніж починати снідання, старійшина ламав хліб, брав частку від страв і кидав це у вогнище, бо, як вірили, під ним жили душі пращурів (С. Скляренко) vs розламати (подія): Він розламав шиаток на кілька частин, найбільшу лишив собі, решту роздав своїм близьким (I. Росоховатський) vs розламувати (процес): Одержавши буханець, Володя тут же розламував його на шматки і роздавав найбільш знесиленим в'язням, при иьому жодного разу не обминув Таню, Янека і його дідуся, віддаючи хлопчині найбільші частки (В. Малик).

Частина наведених вище ілюстрацій репрезентують один із ефективних прийомів комплексної аспектологічної діагностики - методику нативно-корелятивних дискурсів - вилучених із текстів речень або мінімальних фрагментів, які нативно («за природою») відображають ситуації, яким притаманний цілісний внутрішньочасовий контур, що досягнено завдяки поєднанню в тому самому контексті обох видових партнерів: імперфектива й перфектива, пор.: ламати vs зламати: Стали двері ламати, Настасю добувати; дев'ятеро дверей зламали і Настасю достали... (П. Загребельний).

Незаперечним каноном суто видового партнерства (традиційної «суто видової парності») - однієї з найбільш характерних рис термінативного аспектуального класу є «критерій Маслова» (Маслов, 1948, с. 307) як тест на можливість транспозиції перфективної конструкції минулого часу в імперфективну конструкцію теперішнього історичного за умови незмінності лексичної семантики. Основним діагностичним контекстом тут слугує теперішній історичний час (praesens historicum) - наратив, що передбачає «занурення» оповідача в минуле, своєрідне «оживлення» колишніх подій, інтерпретацію їх як актуальних, таких, що ніби відбуваються перед очима спостерігача. Це може бути досягнуто шляхом заміни форми минулого часу на форму теперішнього, а отже, і дієслів доконаного на дієслова недоконаного виду, пор.: Мати розгорнула хустку, в якій принесла з поля дві пориії пайка-макухи, розламала на дві рівні частинки й пішла з хати (І. Кирій) і Мати розгортає хустку, в якій принесла з поля дві пориї пайка-макухи, ламає (розламує) на дві рівні частинки й іде з хати (трансформація у praesens historicum).

Аспектуальну синонімію безпрефіксного й суфіксального імперфективів підтверджує їхня взаємозамінність у тексті: як заміна префіксального 
імперфектива на безпрефіксне дієслово недоконаного виду, так і зворотна заміна, пор.:

1) розламувати - ламати: По дорозі зупинясться, розмовляє з людьми, купує кавуни на південних базарах, засмагає під кримським сонцем. I так біблійно розламує [ламає] коровай, так картинно роздає його в простягнуті руки... (Л. Костенко);

2) обламувати - ламати: Збирали паливо в гаю за селом - хто знаходив галуззя й під снігом, а хто обламував [ламав] на деревах (Є. Гуцало);

2) ламати - переламувати: Голіаф жадібно дивився на свій крихітний шматочок, коли ламав [переламував] його надвоє кілька хвилин перед изим (І. Багряний);

3) ламати - відламувати: Iжовті крихкі маторженики лежали на столі перед його очима, ніби учора був дитиною $і$ ламав [відламував] од них по куснику, примчавщи виголоднілий з вулииі (В. Дрозд).

Термінативні ж суто видові партнери ламати vs поламати: ламати (процес) «розділяти щось на частини або відділяти частини чого-небудь; руйнувати що-небудь»: Вітер в гаї нагинає Лозу і тополю, Лама дуба, котить полем Перекотиполе (Т. Шевченко) vs поламати (подія): Замуміло в полі, вихор пролетів, Поламав три дуби - велетнів лісів (Олександр Олесь) з огляду на відсутність префіксального імперфектива *поламувати, перебувають поза межами видових трійок.

Водночас слід відзначити і аспектуальну специфіку видових партнерів ламати vs зламати, яка зазнає розширення у видову трійку ламати vs зламати vs зламувати лише в проілюстрованому вище значенні «згинаючи що-небудь, надавлюючи на щось, відділяти, відламувати частини, шматки від чого-небудь», іншим семантемам притаманне лише двочленне видове партнерство:

1) ламати vs зламати: ламати (процес) «робити непридатним для використання, псувати ударами, поштовхами тощо»: Ви тільки уявіть собі той встид... полковник зриває мені еполети, ламає шаблю...(Ю. Винничук) vs зламати (подія): Буйвіда витяг з-під його бока свою придавлену ногу, дістав $з$ піхов шаблю, зламав ї̈ об коліно і кинув під копита Наливайковому Резі (М. Вінграновський);

2) ламати vs зламати: ламати (процес) «руйнуючи, розбиваючи на частини, нищити, ліквідовувати що-небудь»: $B$ донських степах дійшло до того, що не було й лісу, щоб накривати бліндаж для Старшого. Ламали хати, тягли звідти дерево... (П. Загребельний) vs зламати (подія): - А тому, щяо я, Діма, лишився вчора без домівки. - Як без домівки?! - Зламали мою домівочку, ой, зламали! - забідкався, затужив Діма... Так-от, коли зламали мій будиночок, книга пропала під уламками (А. Костецький);

3) ламати vs зламати: ламати (процес) «позбавляти кого-небудь сили, енергії, волі, знесилювати фізично або морально»: Ці опуси, твердять наші середньовічні вчителі, згинали, мішали із землею, ламали на друзки всіх. Усіх, але, виходить не Доктора? (Л. Коваленко) vs зламати (подія): ... вчинками своїми він неспростовно засвідчував: зламали його святенники з храму, здолали його волю, змусили діяти за своїми злодійськими вказівками (Ю. Ячейкін);

4) ламати vs зламати: ламати (процес) «рішуче відкидати, руйнувати, нищити або порушувати що-небудь традиційне, звичне, усталене»: Поляки не вперше $i$ не востаннє ламали договори та угоди (С. Добровольський) vs 
зламати (подія): Жеруть себе, щьб Лях позвав на пир; Замість з народом станути на брани Зламали вічний заповіт за жир! (В. Пачовський);

5) ламати vs зламати: ламати (процес) «вигинати під кутом, змінивши звичайний вигляд, попередній контур»: Варя Юхимівна якусь мить стояла, ламаючи брови, потім вуста ї̈ рішуче зімкнулися (А. Дімаров) vs зламати (подія): Наталка вмить спалахнула, здивувалась. Почервоніла, зламала брови i відвернулась (І. Багряний).

У сенсі удокладнення аспектуально-лексичної парадигми слід відзначити диференціацію термінативів на пантиви, що відображають поступове здійснення процесу, та тотиви, що позначають його одномоментне здійснення, що залежить як від внутрішнього контексту (аспектуально вагомого лексичного значення), так і зовнішнього (наявності аспектуально значущих синтаксем, переважно адвербіальних), пор.: Потім узявся за юніорів. Сдиний, хто з ним не пив, - Марат! Два дні ламав його Чорний, два дні спокушав (С. Жадан) і Раптом ламас об коліно свою подорожню палищю... Причепленим до шкуратяного паса ножем зарівнює обломлені кіниі (Н. Королева).

Визначальною рисою аспектуально-прагматичної мікропарадигми термінативів $€$ притаманність прогресивної функції, що полягає у відображенні конкретного актуально-тривалого процесу, пор.: Гликерія, глянувши до цеентру, бачить, як Дунька, бліда, з великими зляканими очима ( $і$ через це дуже гарна), хутко кваплячись, ламає хліб, соває в купу рук, простягнутих до неї (В. Винниченко), що підтверджує можливість актуального діалогу - відповіді на запитання: - Що вона в ию мить робить? - Ламає хліб.

Аспектуально-дериватологічна парадигма термінативного дієслова ламати передбачає акціональне партнерство. Здебільшого це лексикографічно не зафіксовані (а якщо зафіксовані значення, то відсутні ілюстрації) префіксальні семантеми, тому більшість із них підтверджені авторськими ілюстраціями, що засвідчує їхню потенційну можливість. Зокрема, термінативній семантемі дієслова ламати «відокремлювати листя або плоди від стовбура»: По городах ламають кукурудзу, копають бараболі, рубають каnусту (У. Самчук) притаманні такі види акціонального партнерства:

1) термінативно-редуплікативне: ламати vs пополамати «ламати багато разів, тривалий час»: За своє довге селянське життя пополамала вона ту кукурудзу, попокопала ту бараболю, попорубала ту капусту;

2) термінативно-делімітативне: ламати vs поламати «ламати упродовж якогось, зазвичай нетривалого часу»: А я поки що за Любу поламаю кукурудзу, бо ламатиме вона тут до ранку, а норми не виконає!.. (П. Автомонов);

3) термінативно-пердуративне: ламати vs проламати «ламати упродовж якогось, зазвичай тривалого часу»: Сьогодні перед нами стояло завдання: ламати кукурудзу. Цілий день проламали, але норми так і не виконали;

4) термінативно-фінітивне: ламати vs відламати «ламати тривалий час, віддавши праці багато сил; перестати ламати з огляду на старечий вік»: Бабусю, допоможіть кукурудзу ламати, бо он дощ насуває. - Я вже, дитино, своє відламала;

5) термінативно-сатуративне: ламати vs наламатися «багато ламаючи, дуже стомитися»: Сьогоріч кукурудза зайняла більшу частину городу, та й уродила нівроку. Ото вже ми ї̈ наламалася;

6) термінативні-пейоративне: ламати vs доламатися «багато ламаючи, доводити себе до неприємних наслідків»: Цілий тиждень ламаючи кукурудзу, доламався до того, що обидві руки були в подряпинах та порізах; 
7) термінативно-кумулятивне: ламати vs наламати «ламати щось у якій-небудь, зазвичай великій кількості»: Старий наламав калини иілий кіш і подався до Буркуна, щоб звідти глянути на Ріку (М. Дочинець);

8) термінативно-дистрибутивне: ламати vs переламати «ламати багато чого-небудь»: Скільки грядок перепололи, скільки картоплі перекопали, скільки кукурудзи переламали за свій вік иі тендітні на вигляд руки;

9) термінативно-тоталітивне: ламати vs виламати «ламати вичерпну кількість, усе»: За день сусіди виламали геть усю кукурудзу.

Унаслідок пропозиційного зсуву - опущення прямого додатка перехідне дієслово ламати набуває ознак псевдонеперехідного, або дієслова 3 нульовою перехідністю, що зумовлює його перекатегоризацію з термінативного значення в активітивне, а отже, й утрату суто видового партнерства, напр.: Це плуг, щзо його рухають мільйони мускулястих рук, вітер, щэо "рве, ламає, 3 землі вириває», космічний оркестр революиї (Із часопису).

Незрідка термінатив ламати, що виражає здійснення конкретного (здебільшого фізичного, пов'язаного з певним різновидом трудової діяльності) процесу, спрямованого на створення чи перетворення матеріального об'єкта, зазнає перекатегоризації в активітив зі значенням «бути зайнятим здійсненням конкретного (переважно фізичного, пов'язаного з одним із виявів трудової діяльності) процесу безвідносно до його результату»: Підігнувши під себе ноги. сопучи і підиморгуючи, Валя висиджував у майстерні Палаиу до самого вечора, майстрував, ламав, переробляв готове, доки сторожиха змушена була нагадати, що пора вже йому збиратися додому (О. Гончар). У цьому разі перед нами - різна мовна інтерпретація того самого екстралінгвального факту. Семантика термінативів $\epsilon$ адекватною реальній ситуації, оскільки називає всіх її учасників, реальна ж ситуація, відображувана активітивами, зазнає певної корекції з боку мовних засобів - абсолютивне вживання перехідного дієслова трансформує трикомпонентну «за природою» ситуацію у двокомпонентну синтаксичну модель: Nnom -Vf. Отже, неназивання одного з учасників ситуації засвідчує реалізацію іншої семантеми. Значення «бути зайнятим чим-небудь» виокремлено в одинадцятитомному „Словнику української мови” лише в деяких дієслів як відтінок.

Одна семантема полісеманта ламати «викликати хворобливе відчуття ломоти» (як у перехідному, так і в неперехідному варіантах), відображаючи актуальний стан, належить до стативів, що позбавляє ії можливості мати суто видового партнера. Стативній семантемі не пртаманна прогресивна функція, натомість властива актуально-статальна - конкретно-видове значення «вияв стану в сучасний для спостерігача часовий інтервал чи момент», пор.: Biн засів у своєму бліндажі $i$ весь день не виходив на білий світ. Його «ламало й морозило» (О. Гончар); Орися батькові не перечила, бо знала, щоо хоч як він ї любить, але супротиву не стерпить. Чула тільки, що щуось ії в горлі скобоче, щось губи ламає $і$ в очах палить (Б. Лепкий): Він відчув, щуо тиф ламає його на всі боки, дихати важко, в голові стукотять молотки (О. Гончар).

До релятивів, що позбавлені видового й акціонального партнерства та прогресивного значення, належить не зафіксована в одинадцятитомному «Словнику української мови» «географічна» семантема ламати, що позначає просторові відношення: розташування в просторі одного матеріального об'єкта стосовно іншого. Специфіка релятивних семантемам виключає будь-яке партнерство, а серед функцій передбачає здебільшого гномічну як конкретно-видове значення недоконаного виду в контексті теперішнього 
позачасового (атемпорального), напр.: Рушив у бік густих заростей, які ламали рівну лінію дерев, щзо стояли уздовж берега озера (К. Лоумер).

До аспектуального класу евентивів дієслово ламати належить, функціонуючи з лексикографічно не виокремленим значенням, що відображає непрогнозовану, несподівану, небажану подію («випадок», «пригоду» тощо) Означаючи цілеспрямовану фізичну дію, спрямовану 3 боку суб'єкта на порушення цілісності чи первісного стану чого-небудь, дієслово ламати є термінативом, що передбачає наявність суто видового партнера зламати та прогресивну функцію, актуалізовану в контексті актуальної тривалості (що він робить у цей момент часу?). Пейоративна ж подія, суть якої нецілеспрямований, несподіваний, непрогнозований, непередбачуваний чи небажаний для суб'єкта наслідок його діяльності, вимагає евентивного формату, який передбачає видове партнерство з імперфективом, але заперечує його вживання в контексті актуальної тривалості, не виключаючи контексту ітеративності. Як і термінативи, евентиви належать до парновидових дієслів, але їхн парновидовість має інший характер: термінативне партнерство як у мовному, так i в когнітивному аспекті $\epsilon$ гетерогенним: імперфективи означають подієспрямований процес, а перфективи - подію як неодмінне його завершення, повну реалізацію стосовно своєї внутрішньої межі. Евентивне ж партнерство в мовному плані - гетерогенне, а в когнітивному - гомогенне: як перфективи, так і імперфективи позначають подію, пор.: термінативи ламати (процес) vs зламати (подія): Він бив машину щзо було сили, ..крутив головки гайкам і ламав все, щзо вдавалось зламати (М. Коцюбинський) і евентиви ламати (подія) vs зламати (подія): Досліджував ландшафт і природні умови Запорозького краю, перепливав на дубах Дніпрові пороги, неодноразово ламав руку, тонув у Дніпрі, був засипаний землею в кургані (А. Парамонов) vs Він торік зламав руку на лижній трасі (М. Дяченко). Отже, термінативам властиве суто видове партнерство, а евентивам - функційно-видове.

Висновки. Комплексна аспектологічна діагностика полісемічного дієслова ламати та моделювання його аспектуальної макропарадигми засвідчує наявність у його аспектуально-лексичній мікропарадигмі семантем, що належать до п'яти різних аспектуальних класів: термінативів, активітивів, евентивів, стативів і релятивів. Аспектуальний клас визначає відповідний тип мікропарадигм: 1) термінативам притаманні суто видове, функційно-видове й акціональне партнерство, прогресивна функція; 2) активітиви не мають видових партнерів, натомість їм властиві акціональне партнерство та прогресивна функція; 3) стативи позбавлені можливості мати видових партнерів і прогресивну функцію, але їм притаманна актуально-статальна функція; 4) евентивам не притаманне суто видове партнерство, натомість властиве функційно-видове, вони позбавлені прогресивної функції, натомість наділені ітеративною; 5) семантика релятивів унеможливлює будь-яке партнерство та прогресивну функцію, їм притаманна гномічна, потенційна та континуальна функції.

Комплексне дослідження закономірностей категоризації аспектуальної семантики на засадах об'єктивістського підходу відкриває перспективи для багатопланового аналізу аспектуальності й виду. Застосування комплексної аспектологічної діагностики вможливлює виявлення всього спектра аспектуальних характеристик дієслівної лексеми й найтонших нюансів іiі аспектуальної поведінки, а отже, об'єктивне моделювання аспектуальної парадигми. 


\section{Бібліографія}

Калько, М. І. (2009). Аспектуальні класи українського дієслова на тлі класів 3. Вендлера. Украӥнська мова. 3. 17-27.

Калько, М. І. (2013). Аспектуальність : категоризація, класифікація і репрезентація в сучасній українській літературній мові. Черкаси: видавець Чабаненко Ю. А.

Карпухин, С. А. (2008). Семантика русского глагольного вида. Автореф. дис. доктора филол. наук : спец. 10.02.01. Самара.

Лайонз, Дж. (2003). Лингвистическая семантика: Введение. Москва: Языки славянской культуры.

Маслов, Ю.С. (1948). Вид и лексическое значение глагола в современном русском литературном языке. Известия АН СССР. Отделение литературы и языка. VII. 4. $303-316$

Плунгян, В. А. (1998). Грамматические категории, их аналоги и заместители. Автореф. дис. доктора филол. наук : спец. 10.02.19. Москва.

Смит, К. (1998). Двухкомпонентная теория вида. Типология вида: проблемы, поиски, решения. (сс. 404-422). Москва: Наука.

Соколова, С. О. (2003). Префіксальний словотвір дієслів у сучасній украйнській мові. Київ: Наукова думка.

Соколова, С. О. (2009). Словотвірна та аспектуальна парадигма дієслова: проблема співвідношення. Мови та культури у новій Свропі: контакти і самобутність. 3б. доповідей Міжнар. наук. читань, присв. 70-річчю від дня народження чл.-кор. НАНУ, проф., д.ф.н. Н.Ф.Клименко. Київ. 155-166.

Соколова, С. О. (2016). Аспектуальная парадигма базового глагола как его классификационный признак. Scando-Slavica. 62. 1. 79-99.

Ясаи, Л. (1997). О принципах выделения видовой пары в русском языке. Bonpocbl языкознания. 4. 70-84.

Nilsson, M. (Ed.) (2013). The Semantic Scope of Slavic Aspect. Fourth Conference of the International Commission on Aspectology of the International Committee of Slavists University of Gothenburg, June 10 - 14: Abstracts.

Vendler, Z. (1967). Verbs and times. Linguistics in philosophy. (pp. 97-121). Ithca: Cornell University Press.

\section{References}

Kalko, M. I. (2009). Aspektualni klasy ukrayinskoho diyeslova na tli klasiv Z. Vendlera. Ukrayinska mova. 3. 17-27.

Kalko, M. I. (2013). Aspektualnist: katehoryzatsiya, klasyfikatsiya i reprezentatsiya $v$ suchasniy ukrayinskiy literaturniy movi. Cherkasy: vydavets Chabanenko Yu. A.

Karpuhin, S. A. (2008). Semantika russkogo glagol'nogo vida. Avtoref. dis. doktora filol. nauk : spec. 10.02.01. Samara.

Lajonz, Dzh. (2003). Lingvisticheskaja semantika: Vvedenie. Moskva: Jazyki slavjanskoj kul'tury.

Maslov, Ju. S. (1948). Vid i leksicheskoe znachenie glagola v sovremennom russkom literaturnom jazyke. Izvestija AN SSSR. Otdelenie literatury i jazyka. VII. 4. 303-316.

Nilsson, M. (Ed.) (2013). The Semantic Scope of Slavic Aspect. (2013). Fourth Conference of the International Commission on Aspectology of the International Committee of Slavists University of Gothenburg, June $10-14$ : Abstracts.

Plungjan, V. A. (1998). Grammaticheskie kategorii, ih analogi i zamestiteli. Avtoref. dis. doktora filol. nauk : spec. 10.02.19. Moskva.

Smit, K. (1998). Dvuhkomponentnaja teorija vida. Tipologija vida: problemy, poiski, reshenija. (pp. 404-422). Moskva: Nauka.

Sokolova, S. O. (2003). Prefiksalnyy slovotvir diyesliv u suchasniy ukrayinskiy movi. Kyiv: Naukova dumka.

Sokolova, S. O. (2009). Slovotvirna ta aspektualna paradyhma diyeslova: problema spivvidnoshennya. Movy ta kultury u noviy Yevropi: kontakty i samobutnist. Zb. dopovidey Mizhnar. nauk. chytan, prysv. 70-richchyu vid dnya narodzhennya chl.-kor. NANU, prof., d.f.n. N.F.Klymenko. Kyyiv. 155-166. 
Sokolova, S. O. (2016). Aspektualnaya paradigma bazovogo glagola kak yego klassifikatsionnyy priznak. Scando-Slavica. 62. 1. 79-99.

Jasai, L. (1997). O principah vydelenija vidovoj pary v russkom jazyke. Voprosy jazykoznanija. 4. 70-84.

Vendler, Z. (1967). Verbs and times. Linguistics in philosophy. (pp. 97-121). Ithca: Cornell University Press.

\section{Резюме}

\section{Калько Микола}

\section{АСПЕКТУАЛЬНА ПАРАДИГМА БАГАТОЗНАЧНОГО ДІЕСЛОВА (НА МАТЕРІАЛІ ПОЛІСЕМАНТА ЛАМАТИ)}

Постановка проблеми. Аналіз лінгвоукраїністичних здобутків у галузі аспектології засвідчує наявність цілого спектра дослідницьких перспектив, однією 3 пріоритетних серед яких, на наш погляд, $є$ потреба комплексного підходу до опису категорії аспектуальності як динамічного й інтеграційно-багатопланового феномена. Це детермінує доцільність дослідження граматики виду не ізольовано, а з огляду на ії нерозривний зв'язок 3 іншими компонентами аспектуальності, передусім із аспектуальними класами.

Мета статті - застосування об'єктивістського підходу до опису дієслівного виду, що дає змогу, використовуючи відповідний дослідницький інструментарій, створити об'єктивний, удокладнений (а не поверховий, схематичний) аспектуальний «портрет» багатозначної дієслівної лексеми.

Методи дослідження. Комплексна аспектуальна діагностика як інтеграційна методика, що передбачає цілеспрямоване застосування логічного, компонентного, словотвірного, опозиційного та дистрибутивного аналізу, добір корпусу нативно-корелятивних фрагментів дискурсу тощо.

Основні результати дослідження. У статті на матеріалі одного з багатозначних дієслів сучасної української літературної мови унаочнено можливість, доцільність й ефективність застосування об'єктивістського підходу до опису категорій аспектуальності та виду. Доведено, що такий підхід дає змогу, використовуючи відповідний дослідницький інструментарій (у цій розвідці - комплексна аспектологічна діагностика), створити об'єктивну, удокладнену, а не спрощену, схематичну модель аспектуальної парадигми полісемічної дієслівної лексеми.

У розвідці представлено широку інтерпретацію цього поняття - як макропарадигми, що інтегрує: 1) аспектуально-лексичну мікропарадигму, наповнювану аспектуально-лексичними класами: термінативним, активітивним, стативним, евентивним, релятивним; 2) аспектуально-граматичну мікропарадигму, що об'єднує аспектуально-граматичні класи: імперфективипартнери, перфективи-партнери, imperfektiva tantum, perfektiva tantum, 3) аспектуально-прагматичну мікропарадигму як набір конкретно-видових значень (функцій), передовсім - актуально-тривалого (конкретно-процесного, прогресивного), ітеративного, preasens historicum, конкретно-фактичного тощо; 4) аспектуально-дериватологічну мікропарадигму, яка консолідує акціональні 
підкласи (способи, або роди, дієслівної дії) як морфолого-словотвірні префіксальні, суфіксальні, конфіксальні деривати: атенуативи, делімітативи, дистрибутиви, дуративи, пердуративи, сатуративи, семельфактиви, кумулятиви, редуплікативи тощо. Визначальною для специфіки видової корелятивності, спектра функцій, набору акціональних підкласів $€$ належність до того чи того лексичного аспектуального класу.

Висновки та перспективи. Об'єктивістський підхід до дослідження проблем виду, головною тезою якого $є$ розмежування його граматичної та лексичної сутностей, неодмінно диктує і потребу якнайдокладнішого вивчення механізму взаємозв'язку категорії виду з контекстуальним середовищем. Це й становить перспективу подальшого лінгвістичного вивчення механізму взаємодії граматики і словника в царині виду українського дієслова.

Ключові слова: аспектуальна макропарадигма, аспектуально-лексична мікропарадигма, аспектуально-граматична мікропарадигма, аспектуальнопрагматична мікропарадигма, аспектуально-дериватологічна мікропарадигма, аспектуальний клас, акціональний підклас, аспектуальне партнерство.

\section{Abstract \\ Kalko Mykola \\ ASPECTUAL PARADIGM OF A POLY-SEMIC VERB (ON THE MATERIAL POLY-SEMANT ЛАMATИ)}

Background. Analyzing the Ukrainian language aspect studies reveals a spectrum of investigation perspectives. One of them is distinguished in the complex approach to the category of aspect as a dynamic and integrated multi facet phenomenon. It fully determines investigating the aspect grammar not solely but in lieu with other components of the aspect theory, mainly with aspect classes.

Purpose. Through all this, the article is aimed at applying the objectivist approach to describing the verbal aspect that enables, with the appropriate research instrumental means, to create a real and detailed, though not schematic, aspectual «picture» of a poly-semantic verbal lexeme.

Methods. Complex aspectual diagnostics as integrating methods that presume motivated application of logical, component, word-building, oppositional and distributive analyses, selection of native correlative discourse samples etc.

Results. The article, through a modern Ukrainian poly-semantic verb, clearly regards the perspective of employing the objective means for describing categories of aspect and aspectuality. The paper supports the claim that the approach described here enables, through employing appropriate investigatory means (i. e. complex aspectology survey), to create an objective and detailed (instead of a simplified one) schematic model for the aspectual paradigm in poly-semantic verbal lexeme.

Aspectual macro paradigm is constituted by: 1) aspectual lexical micro paradigm consisting of aspectual lexical classes: terminative, activitive, stative, eventive, relative; 2) aspectual grammatical micro paradigm, with aspectual grammatical classes: imperfectives-partners, perfectives-partners, imperfektiva tantum, perfektiva tantum, biaspectives; 3 ) aspectual pragmatic micro paradigm integrating concrete aspect functions, among them progressive, iterative, preasens historicum, concrete 
factual etc.; 4) aspectual derivatological micro paradigm consolidating actional subclasses (traditional genders, or moods), like morphologic word-building prefixal, suffixal, and confixal derivatives: atenuatives, distributives, duratives, perduratives, saturatives, semelfactives, cumulatives, reduplicatives, etc.

Discussion. An objective approach to investigating the verbal aspect perspectives, focused on the opposed grammar and lexical features, will inevitably bring up the necessity for a detailed research of the relations between the aspect category and the context. This appeals for further linguistic investigation of grammar and vocabulary interaction in the research within the Ukrainian verb aspect.

Keywords. Aspectual macro paradigm, aspectual lexical micro paradigm, aspectual grammatical micro paradigm, aspectual pragmatic micro paradigm, aspectual derivatological micro paradigm, aspectual class, actional subclass, aspectual partnership.

\section{Відомості про автора}

Калько Микола Іванович, доктор філологічних наук, професор кафедри украйнського мовознавства і прикладної лінгвістики Черкаського національного університету імені Богдана Хмельницького,.м. Черкаси (Украӥна), е-mail: mkalko@ukr.net

Kalko Mykola, Doctor of Philological Sciences, Professor at the Department of Ukrainian linguistics and applied linguistics Cherkasy Bohdan Khmelnytsky National University, Cherkasy (Ukraine),e-mail: mkalko@ukr.net

ORCID 0000-0001-6042-4436

Надійшла до редакції 01 грудня 2020 року Прийнято до друку 27 грудня 2020 року 